\title{
Thematic maps in Eugeniusz Romer's Geographical and Statistical Atlas of Poland from 1916 - the historical and methodological perspective (on the 100-year anniversary of the publication)
}

\begin{abstract}
The Geograficzno-statystyczny atlas Polski (Geographical and Statistical Atlas of Poland), printed in Vienna in 1916, was elaborated due to remind the world about Poland and the Polish issue. At that time Poland had been partitioned for over 120 years and it was very important to provide comprehensive information about historical Polish territory and its inhabitants before the end of the ongoing war. It was a significant decision because the atlas appeared to be crucial to establishing borders of the Second Polish Republic at the Paris Peace Conference. In 2016 the hundredth anniversary of first edition of atlas is a great occasion for a historical and methodical brief outline.

The atlas was the fundamental work of Eugeniusz Romer, a distinguished geographer, cartographer and geo-politician. All of the 65 maps and 5 diagrams were elaborated by himself and his collaborators: W. Semkowicz, J. Nowak, W. Szafer, S. Weigner, J. Rutkowski, K. Nitsch, B. Chodkiewicz. It includes maps showing physiograpy, administrative division, history of the Polish territory, population, nationality, religion, agriculture, industry and transport, developed on the basis of official data sources. It is noteworthy that $E$. Romer introduced the isarithmic method on a large scale to present both population and socio-economic phenomena.

As an all-embracing work, Atlas played a major role in drawing the boundaries of the reborn Poland in post-war Europe. This also shows that thematic cartography has been an essential instrument in argumentation for the national interest of Poland.
\end{abstract}

Keywords: Geographical and Statistical Atlas of Poland, Romer's cartography, thematic cartography, socio-economic atlases, socio-political function of maps

The upcoming hundredth anniversary of the publication of Eugeniusz Romer's Geograficzno-statystyczny atlas Polski (Geographical and Statistical Atlas of Poland) is an excellent opportunity to remember this piece of work and to conduct an historical-methodological analysis of the maps that had such a great influence on the shape of the reborn Republic of Poland after World War I. Since the outbreak of the Great War, Poles had been very active in the field of so-called congressional cartography. Two publications in 1916 were of importance for Polish interests - the Wojenno-polityczna mapa Polski (Military and Political Map of Poland) published in Lvov and the Geographical and Statistical Atlas of Poland, printed in Vienna. It was easy at that time to justify the need for propaganda in favour of Poland, which existed in a political sense only in theory - on the manifesto of the will of two emperors of the Central States on 5 November 1916. It was much harder, however, to imagine the shape of the future Polish state - which is why the initiative of Franciszek Stefczyk for the publication of an atlas consisting of a collection of dozens of tables with maps, texts and statistics has proven so very important; his evocative images constituting an attractive method of speaking to all those interested about the geographical location of Poland, where Poles live, and their history, culture and socio-economic structure in the past and present. This task was adopted and implemented by Prof. Eugeniusz Romer, who in a very short space of time, and along with a team of experts, elaborated a collection of maps and diagrams which 
appeared in 1916, issued by the Polish Savings and Loans Companies in the form of the Geographical and Statistical Atlas of Poland ${ }^{1}$.

For nearly a century, much has been written about this atlas, which is sufficiently substantiated that its appearance was an event of great importance, and the Atlas became known as a monumental publication and as E. Romer's best achievement (J. Mościbroda, M.Sirko 2004, p. 88). These included critical texts, such as the reviews of the historian and ethnographer R.F. Kaindl (1919) or the economist T. Brzeski (1917), as well as favourable, even enthusiastic texts, expressing appreciation for the originality of the methodology, the approach to the issues and the selection of source materials, such as those of A. Sujkowski (1917), S. Pawłowski $(1916,1923 / 24)$ and the distinguished American historian R.H. Lord (1921). The concept of the comprehensive cartographic development of issues related to the Poles and Poland in the absence of the existence on maps of the Polish state met with keen interest, which was echoed in these and other reviews published scientific journals shortly after the publication of the Atlas ${ }^{2}$. Despite the passage of time, the originality and uniqueness of this work, the high editorial and graphical standard, and above all the use of the isarithmic method for maps presenting population and socio-economic issues are still emphasised. Noteworthy papers by L. Barwińska (1971), and S. Gurba and J. Mościbroda (1982) present the assumptions and characteristics of this method and discuss in depth its use by E. Romer in the Atlas. Both papers also emphasise the role of the discussion that ensued in the reviews of the Atlas in relation to the correctness and legitimacy of the widespread use of isopleths on socio-economic maps, which inspired a number of studies and methodological papers, such as those

\footnotetext{
1 The Geographical and Statistical Atlas of Poland was edited and compiled by Dr Eugeniusz Romer, a professor of geography at the University of Lvov, with the help of many collaborators. Published by Polish Savings and Loans Companies under the Foundation of the National Department, Warsaw and Krakow, Gebethner and Wolff, 1916, hereafter: E. Romer 1916. The Atlas was printed in Vienna, at the Freytag and Berndt Cartographic Publishers and the A. Holzhausen Printing House; the second edition of the Atlas, containing two additional tables, appeared in Lvov in 1921.

2 A list of almost all the reviews of the Atlas can be found in F. Uhorczak (1955, p. 22).
}

by M. Zdobnicka, F. Uhorczak, J. Czekalski, W. Ormicki, J. Haliczer-Staszewski and L. Barwińska (L. Ratajski 1965, pp. 67-74; L. Barwińska 1971, pp. 102-103).

Literature on the Atlas can therefore be divided into two groups: publications discussing the work as a whole, emphasising the territorial range and subject matter and focusing on its important socio-political role, and those emphasising the methodological solutions, including analysis of the maps from the cartographic perspective. It is also a compulsory work for the research legacy of Eugeniusz Romer, and one of the materials quoted in his biography ${ }^{3}$. One of the intentions of the authors of this paper is to provide a brief reminder of this fundamental work on the occasion of the anniversary of its initial publication, as mentioned in the introduction.

The Atlas is a collective work - in addition to Romer's contribution, it included the works of many prominent specialists from various fields. History was elaborated by W. Semkowicz, geology by J. Nowak, flora by W. Szafer, mining by S. Weigner, extensive ownership by J. Rutkowski, linguistic relations by K. Nitsch, and transportation by B. Chodkiewicz's team. The product of this joining of forces was a publication containing 65 maps and five diagrams illustrating physiography, as well as national-political, religious and economic indexes, in 32 tables. As E. Romer wrote in his introduction: "May this illustration of figures on Poland and Poles serve as an education to Poles themselves, and awaken the consideration and kindness of those in whose hands rests the fate of the Polish issue!" (E. Romer 1916b, p. 5). Justifying the initiative to work on the Atlas, E. Romer referred to Stanisław Staszic's booklet, published just over a hundred years earlier, entitled $A$ brief communication on Polish statistics for those who want to liberate this country, and those who want to rule it (S. Staszic 1807). "These same considerations have become for me a driving motive in the development of the Geographical and Statistical Atlas of Poland", wrote E. Romer (1915, p. 5). S. Staszic described the territory of the non-existent state

\footnotetext{
3 See papers in the volume: Eugeniusz Romer-geograf $i$ kartograf trzech epok. Materiały sesji naukowej, Warszawa 16 kwietnia 2004 rok, „Studia i Materiały z Historii Kartografii” T. 19, Warszawa 2004.
} 
as follows: "The extent of Poland and Lithuania, as they were in $1772 \ldots$ This country has natural borders: to the west, the mountain range stretching from the Carpathians and through Silesia; to the south, the great ridge of the Carpathians leading towards the Black Sea; to the north, the Baltic Sea, and between the Baltic and the Black Sea the River Dnieper and marshes of Polesye... There is no country in Europe so divided by numerous rivers..., where nature itself, with its divisions of water, unites the Black Sea with the Baltic Sea" (S. Staszic 1807 , p. 10). However, the major weakness of this publication was the fact that the author did not attach any maps. This was particularly the case because, at the same time, relevant maps anticipating the reconstruction of Poland based on the Duchy of Warsaw appeared on the market (D.F. Sotzmann 1810), and S. Staszic himself had an excellent idea for a geological map of the Polish lands as early as 1806 (S. Staszic 1815).

Over a hundred years later, at the instigation of F. Stefczyk, director of the Foundation for Savings and Loans Companies, E. Romer decided to show the world Poland on the map. Like S. Staszic, he departed from the borders of 1772, expanding the areas of interest on the land on which - as he wrote - "a larger number of Poles are found. Within these borders I tried to give the most comprehensive picture of the nation and its life, avoiding essentially all general synthesis, willing everyone to build an opinion independently, on the basis of the image, with no suggestion from he who gathered the figures. Departing from this principle, I limited the role of the text for the maps primarily to indicating the sources, to explaining the graphical methods and to instructions for reading the maps; here and there are interwoven mere attempts at synthesising in the form of interpretation of the maps, wanting in this way to encourage people to delve into the content and understand its symbols" (E. Romer 1916b, p. 5). Nonetheless, the territorial range of the maps includes the Baltic-Black Sea intermarium between Berlin and Moscow.

The main maps of the Atlas are made at the scale of $1: 5,000,000$, and the collateral maps at the scale of $1: 15,000,000$. The author's foundation was the creation of legible maps with clear statistical images, requiring significant generalisation of the topographic content in accordance with the Romerian principle of cartography that a map should be 'empty' in pretext. Because of the role it would play, the Atlas was furnished with texts and explanations in three languages - Polish, German and French (fig. 1$)^{4}$. In the second edition, published five years later, English translations took the place of German.

The choice of topics was dictated by the need and desire to reflect as closely as possible the current state of the issues and the phenomena of particular relevance to the 'Polish issue' (S. Gurba, J. Mościbroda 1982, p. 82). The materials for the development of the Atlas were provided by the library of the Central Statistical Commission, almost all ministries of Austria-Hungary and Germany, the Chamber of Commerce and Industry, the libraries in Vienna and Krakow, and the private collections of Professor F. Bujak, a historian of Polish economy and society. Far-reaching support was also received from cultural and economic associations, which enabled the source-based exposition of issues related to education and credit cooperatives. Particularly invaluable was the support of F. Stefczyk, to whom the whole initiative of work on the Atlas owed its financing (E. Romer 1916b, p.5). E. Romer used official statistical data in order to avoid charges of a political bias, noting that the entire cartographic material was based on the first description of statistical source materials covering the whole of the Polish lands, and had been drawn up for Polish ends (E. Romer 1917, pp. 570-573). $\mathrm{He}$ also consciously chose indexes expressed in relative terms, and avoided the absolute values predisposed to rapid outdating (S. Gurba, J. Mościbroda 1982, p. 83).

The statistical data used generally refers to the counties (powiats). The ranges of particular values are illustrated with a colour scale or a variety of hachures, which are clear and appropriately selected for the phenomenon. To fully present the selected issues and show them as completely as possible, two to three indexes were also used on one map, presenting them, for example, in the form of complex choropleth maps. The selection of appropriate graphic mediums guaranteed the readability of maps.

\footnotetext{
${ }^{4}$ All figures included in the text are from the first edition of the Atlas, the copy held at the University Library in Wrocław (ref. 680-III.B).
} 


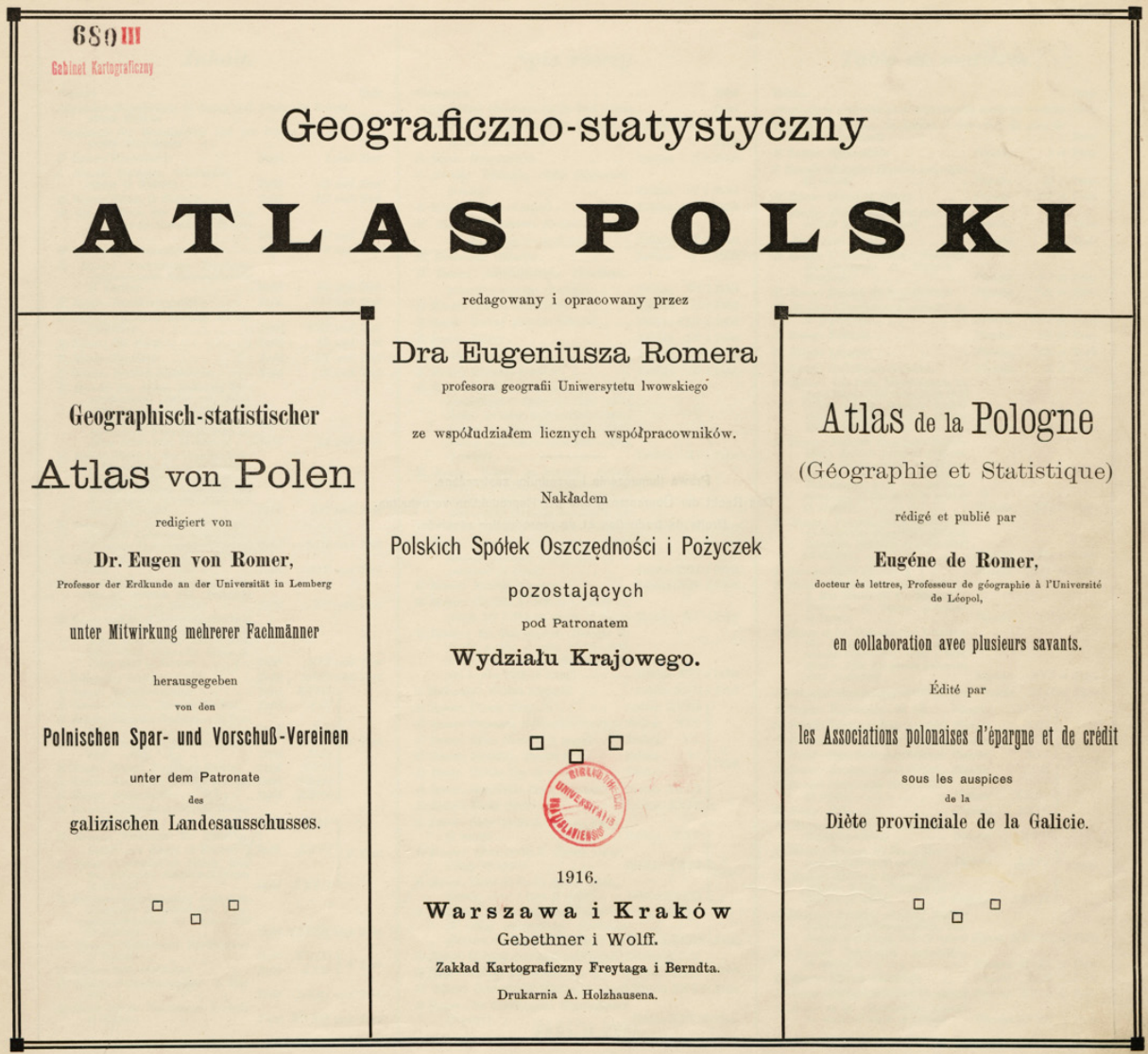

Fig. 1. Title page of the Geographical and Statistical Atlas of Poland by E. Romer, the 1st edition, 1916

Undoubtedly one of the Atlas' main features is the methodical innovation expressed in the use of isopleths to present 'discontinuous' phenomena (population, socio-economic). This is all the more evident with the prevalence of maps developed with the isoline method - there are 34 of these, from a total of 65 , of which 30 are devoted to socio-economic topics (12 population maps, 18 maps showing ownership and land use, structure of crops, cattle breeding, industrialisation and the state of people's savings). As noted by L. Barwińska (1971, p. 100), E. Romer was a pioneer of economic isarithmic (isopleths) maps for atlases, but his use of this method was not a result of his theoretical reflections on the method itself as such, but a consequence of searching for the most appropriate form of presentation on a map of specific phenomena and issues. There is no doubt that he was able to achieve uniformity and methodical cohesion, expressed in the consistent use of selected methods: isopleths (usually when the phenomenon occurs over a large area and the data relates to small area units) and choropleth maps (when the map shows a small area or the data relates to large units) - often used in the form of complex choropleth maps. Several maps in the Atlas were developed using the graduated diagram method, or using qualitative symbols and ranges.

Looking at the next tables of the Atlas, it is clear to see the features of Romerian cartography 


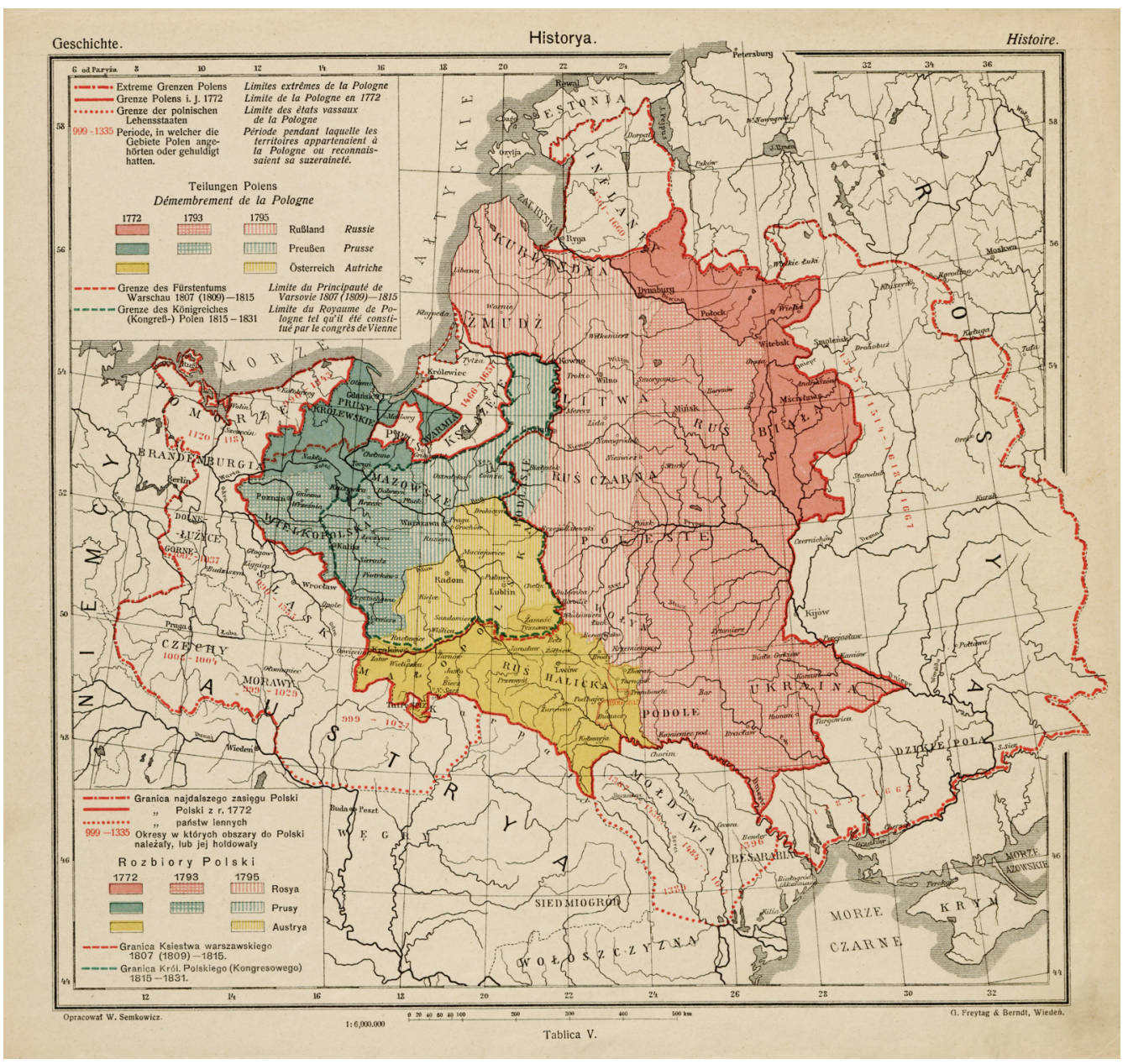

Fig. 2. Table V. Historya (History)

that are so characteristic of his cartographic work. He used isohips on the physical maps, colouring the spaces between them and isolating 'height layers' according to the K. Peucker colour scale (E. Romer 1916b, Table I), and he consistently used isotherms on the climate maps. Interestingly, in the textual analysis of the image of the oceanic-continental climate transition emerging from this map, the author notes the existence between Wrockaw, Riga and Kiev of a 'uniform Polish climate' (Table III), which is quite a bold thesis for a geographer specialising in climatology. It is precisely because of the climate that a large diversity of floristic physiognomy is visible, varying from the Baltic to the Black Sea, which is expressed particularly in the strong transformation of the forest formations shown on the map by W. Szafer (Table IV).

One invaluable element in the Atlas is W. Semkowicz's map, which presents Poland within its historical boundaries, recalling its shape before the partitions (1772) and the territorial changes of the period 1807-1815, and with lines marking the furthest extent of growth of the Polish state in all directions, covering a substantial area of Europe between the middle of the Elbe and the lower Dnieper in an area far exceeding one million square kilometres (Table V - fig. 2). However, these are in no 
way the lines of the range of Polish territorial claims, but merely a reference to the past. The same holds for the administrative range of the provinces of the Polish lands in terms of the occupying states on the map, edited by E. Romer himself (Table VI). In fact, this map covers not only the partitioned areas, but also the East Prussia province and two Silesian districts: Opole and Wrocław. Here too, the point is not the range of potential territorial claims, but rendering the space to which the concept of Poland could relate, and for which the authors of the Atlas studied various statistics, in order to present a comparison of their diversity and demonstrate their greater and lesser associations with Polishness.

Most vividly, these associations came with demographic data (Tables VII-XIII) which, on the basis of statistics on the occupying states from the first decade of the twentieth century, show the population density, the dynamics of population growth and Polish and non-Polish population distribution in the analysed area. Admittedly, in the description of the maps, both authors (E. Romer and K. Nitsch) explain the intricacies of the interpretation of the partition state (Prussian, Russian and Austrian) statistics, which were certainly not pro-Polish and imply that the language of a given people is not always associated with a particular national feeling (for example, with Silesians, Masurians or borderlanders), but the image remained on the map (Table IX - fig. 3).

The image of religious proportions was shown in a similar way (Table X). Here it is not only the percentage decrease of Catholics

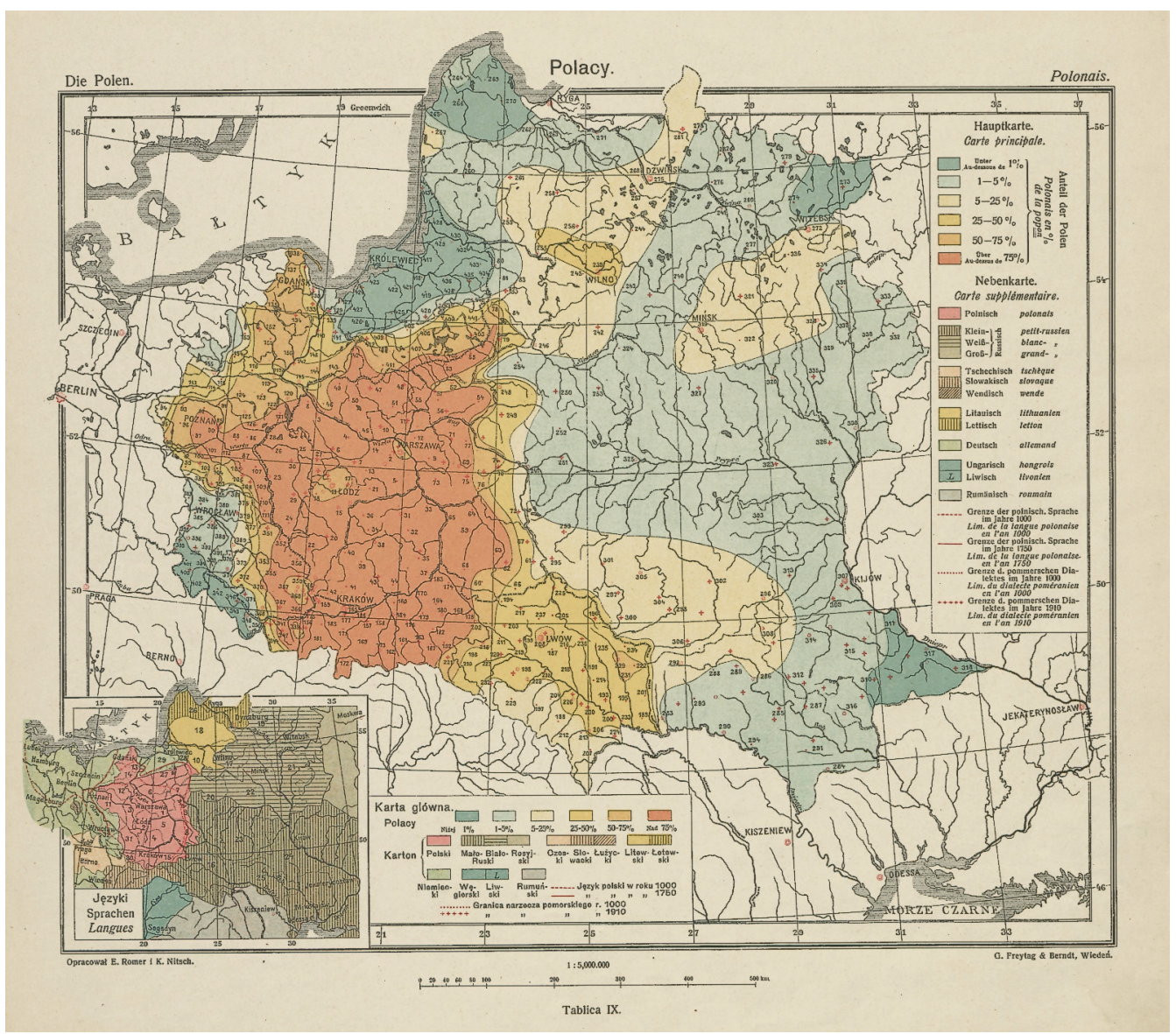

Fig. 3. Table IX. Polacy (Poles) 
from west to east that grabs the attention, but also the border line of the settlement area of the Jewish population, which with few exceptions coincides with the inter-partition PrussianRussian and Austro-Prussian border (fig. 4). Meanwhile, E. Romer provides an interesting analysis of the movement of the Polish and Jewish populations on the four maps in Table XI, where clear changes are seen in the proportions of national ownership in the late nineteenth and early twentieth century in all provinces of the Polish lands of the occupying states. It is significant that the author did not restrict himself to population censuses, but also took into account other statistics, such as the increase in the percentage of Polish pupils at Prussian schools, the progress of the Colo- nisation Commission under Prussian rule, the phenomenon of mass Catholic proselytising in the Chełm province, and Polish ownership in the Lithuanian-Russian borderlands. The analysis of these factors leads to an entirely unexpected finding relating to Polish ownership, which is much larger than indicated by the official statistics of the partitioning powers. It suffices to quote Romer's conclusion that "at least $180,000 \mathrm{~km}^{2}$ of land in Lithuania and Russia is in private Polish ownership, i.e. likely more than that (...) in the Kingdom of Poland in the partitions of Austria and Prussia put together!" (Tables XII, XIII and XIV).

A separate table was devoted to the administrative divisions of the Roman Catholic Church, illustrating the density and size of the parishes

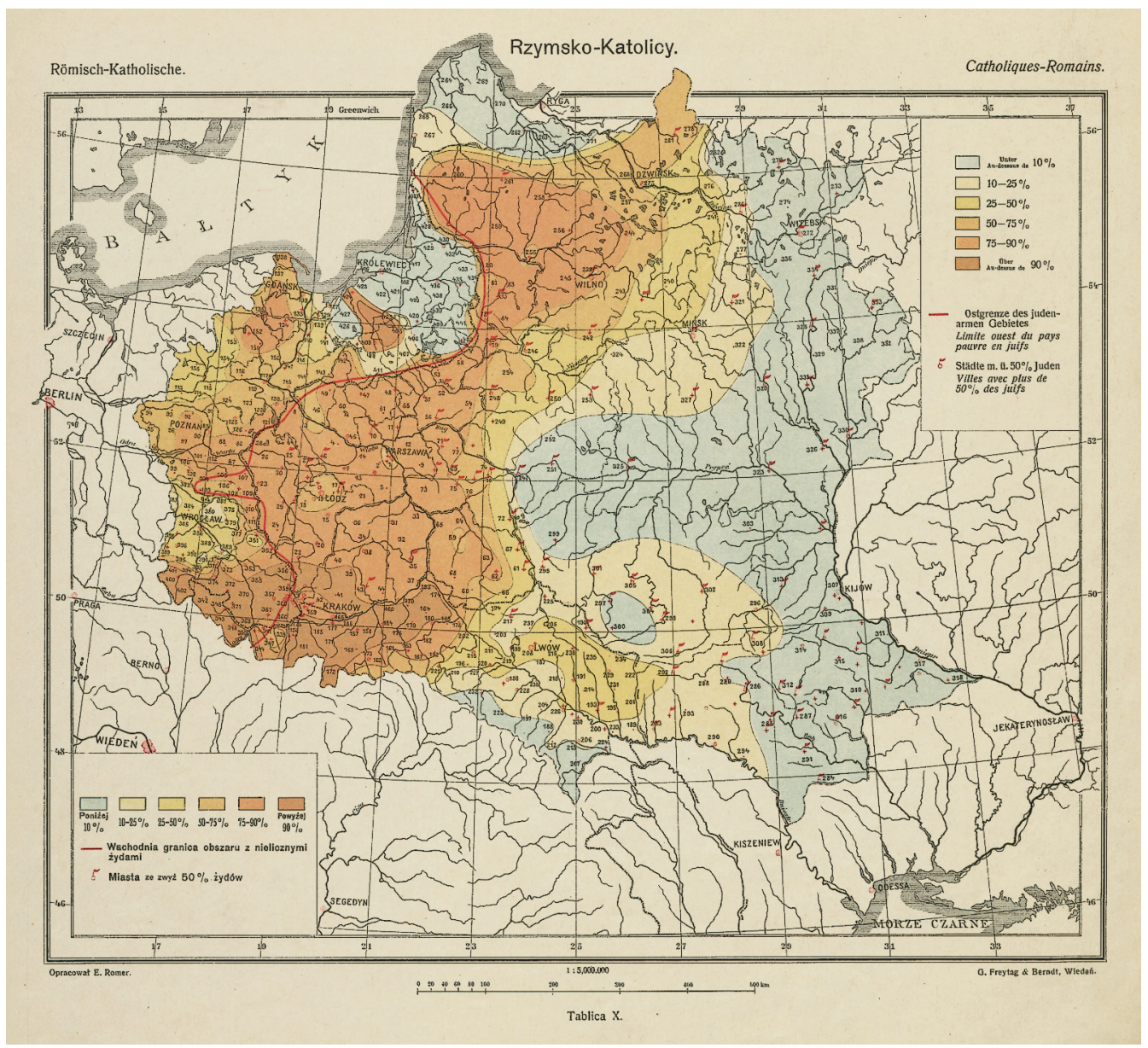

Fig. 4. Table X. Rzymsko-Katolicy (Roman Catholics) 


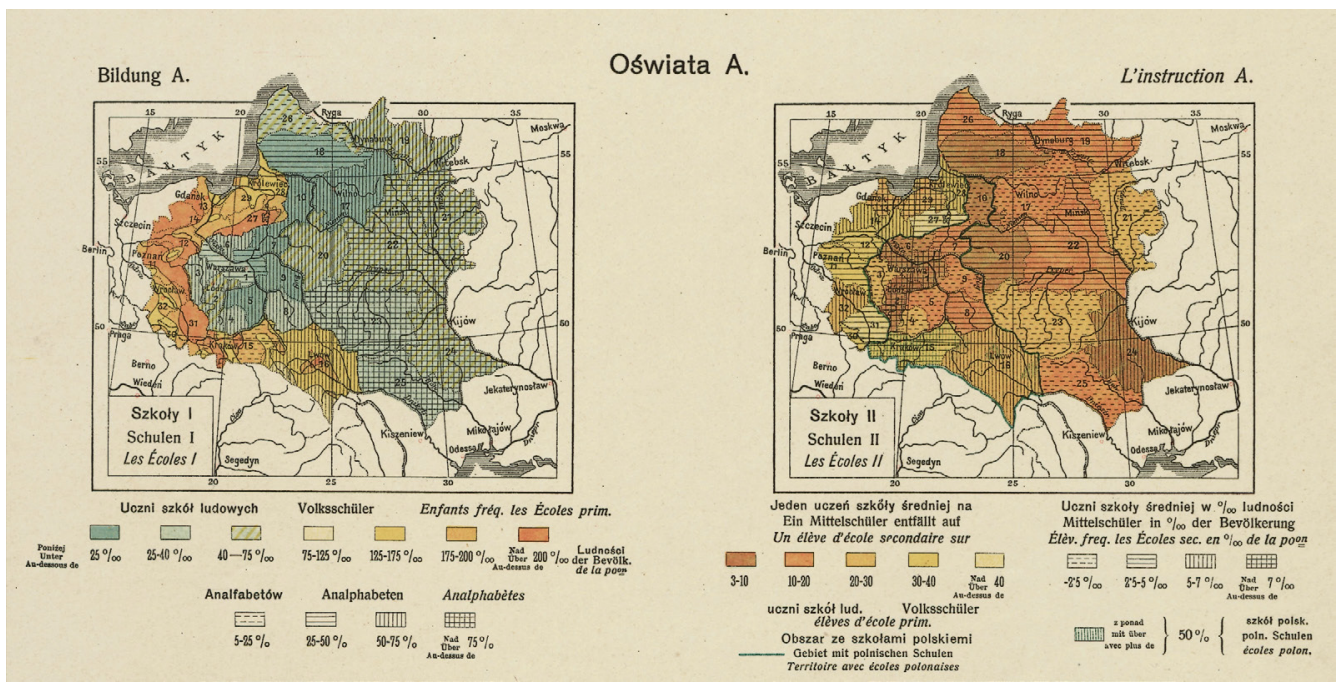

Fig. 5. Table XV. Oświata A (Education A)

in terms of both area and number of followers (Table XIV). Essentially, this phenomenon reflects the ownership of Roman Catholics shown in Table $X$ - except that, in this case, it was interpolated within the diocese borders rather than those of the states. Due to the quality of the statistical data source material in the area of the Russian partition, this map gives a more reliable picture of national affiliation than the map of the Polish population, which was established on the basis of falsified official census data (J. Mościbroda, M. Sirko 2004, p. 90).

The two tables showing the topics of education and culture deserve close attention, even if only in terms of the Polish printed publications. The data for primary education essentially highlights a civilizational gap in access to mainstream education between the partitions cordoned off by the Russian border. On Polish lands under Prussian and Austrian occupation, virtually all children under the age of ten had compulsory access to mainstream school, resulting in zero or at least low levels of illiteracy. Meanwhile, in the Russian zone, the low level of access to school resulted in catastrophic illiteracy, often exceeding $75 \%$ of the population. However, a higher percentage of pupils completed middle school in the Russian zone, which is clear proof of the elitism of education under the Russian occupation (Table XV). In order to show the phenomenon properly and to maximise the use of their data, E. Romer used an interesting methodical procedure for the map Schools for the territory under Russian rule he used a choropleth, constructed on the basis of data from provinces with large surface areas, while for the territories of the Prussian and Austrian partitions he used the isarithmic method, interpolating the values from the source data relating to the much smaller administrative units (fig. 5). The sources of printing, literature and the Polish press, which were also constantly changing during the partition period, were treated alongside education. The next four maps clearly show the process of the shifting of the centres of Polish culture from north to south (from Vilnius to Lvov), from the increasingly restrictive Russian partition to the liberally reformed and eventually re-Polonised Austrian partition, with the position of Warsaw remaining dominant and the surprising leading position of the subscription of Polish press in the Prussian partition, which was the subject to brutal Germanisation (Table XVI).

The final thematic category in the Atlas is the economy. Ranging from agriculture to industry, finance and transportation, the economic foundations of the Polish lands are shown on the maps and extensively characterised in the descriptions. J. Rutkowski, the author of table XVII, 
concludes that "in terms of the agricultural system, the lands of the former Poland represent a compact territory, distinguishable from that of the neighbouring countries, while the different economic development and differences in agricultural policy during the partitions failed to transform the uniform basis of that system, which resulted from joint historical development" (Table XVII). However, his map showing the spread of land ownership at the beginning of the twentieth century seems not to confirm this thesis, since the differences in the percentage share of extensive ownership between central districts and the borderlands are huge. Large farming properties dominate in the lands taken away by Russia and in the Prussian partition, in contrast to the fragmentation of Galicia and the Polish Kingdom area. Table XVIII shows not only the proportion of agricultural land in Poland, but also dispels the myth of the richness of the forests which, with the exception of areas near the Dnieper, had been effectively deforested by the nineteenth century.

Tables XIX-XXIII illustrate livestock and the cultivation of cereals and potatoes. Even with the proviso of methodological differences and incomplete statistics from all three partitioning powers, the differences in agriculture and agricultural productivity between the Prussian region and the other regions is blatant, particularly in the production of bread cereals and the breeding of pigs and cattle (Tables XXIV-XXVI).

One table by $S$. Weigner is dedicated to an elaboration of the mineral resources of the Polish lands. The map shows the geological layers of discovered materials and their actual mining. A side sketch shows the 'Silesian-Polish Industrial District, also referred to in the explanatory text as the Silesian-Cracovian coalfields, distributed unevenly across the Prussian, Silesian-Moravian, Galician and Polish Kingdom areas. A separate diagram illustrates the actual extraction of each raw material and the clear domination of Prussian Upper Silesia in all mining statistics. It is worth noting that, at the beginning of the twentieth century, the Polish territories were not only the world leader in coal mining, but also in oil mining in the Carpathians. Other major elements of extraction and production were iron ore, zinc, lead and rock salt (Table XXVIII).

The next two tables (XXIX and XXX) show that the distribution of raw materials only par- tially influenced the development of industry and, therefore, the employment structure of the population. These factors were more dependent on the political affiliation of the territory than the geographical distribution of natural resources. Although the concentration of industry and population employed in the western part of the presented area is unsurprising, the differentiation between regions is extremely large - especially the industrialisation of three districts: Warsaw, Łódź and Silesia. In the description of this phenomenon, E. Romer himself admits that, in particular partitions, "the industrial statistics are realised according to such disparate rules that no standard can be used for cartographic development" and, as a result, "the two maps showing the proportions of industry in Poland are merely hypotheses".

More numerically tangible, but no less vivid in the differences between the partitions, is the subject of Polish savings at cooperative banks. E. Romer presents this phenomenon on a map, describing precisely in the text its history from the time of S. Staszic, who pioneered the bank fund at the Agricultural Society in Hrubieszów, to the incredible cash booms, such as Raiffeisen's, in Prussia and Austria in the first decade of the twentieth century. Great Poland (Wielkopolska), Warmia and Silesia are clearly at the fore in terms of the culture of saving, eclipsing even the proud and deserving (for financing the Atlas, among other things) Galician Savings Company. Meanwhile, large areas of the Russian partition appear to be extremely poor, the majority being generally deprived of Polish credit cooperatives (Table XXXI).

E. Romer leaves for the end a topic that arouses emotions to this day - the country's inconsistencies in transportation between the former parts of partitions. With the wonderfully dense Prussian railway infrastructure in the west and the average Austrian infrastructure in the south, the Russian part of the Polish lands is practically a black hole, especially in the provinces of Kalisz and Płock, which have very scant rail connections despite bordering the German part of partitions. It looks as if the Russian invaders specifically wanted to fence off the Polish Kingdom from Europe. Unfortunately, despite Poland's independence, this civilizational gap has yet to be effectively breached. 
By publishing the Geographical and Statistical Atlas of Poland, Eugeniusz Romer developed a set of materials to be used both by the Allies (including the American, French and British delegations) and by the Geographical Office via the Polish delegation to the Paris Peace Conference (1919-1920) to support Poland's territorial claims. As a result, this work played a major role in shaping the borders of the reborn Republic of Poland. In 1921, the materials developed by Romer's team in Paris were also published in a revised edition in the form of the Polski atlas kongresowy (Polish Congressional Atlas), which presented an additio-

\section{Literature}

Barwińska L., 1971, Metoda izarytmiczna w mapach ludnościowych i społeczno-gospodarczych Eugeniusza Romera. „Polski Przegląd Kartograficzny” T. 3, nr 3, pp. 97-105.

Brzeski T., 1917, Zagadnienia geograficzne Polski. Z powodu „Atlasu Polski” prof. Romera. „Kwartalnik Historyczny" T. 31, z. 4, pp. 427-484 and 586-595.

Gurba S., Mościbroda J., 1982, Geograficzno-statystyczny atlas Polski Eugeniusza Romera - pomnikowe dzieło kartografii polskiej. „Polski Przegląd Kartograficzny” T. 14, nr 2, pp. 78-86.

Kaindl R.F., 1919, rev.: Romer E. v., GeographischStatistischer Atlas von Polen. „Petermanns Mitteilungen" Jg. 65, p. 69.

Lord R.H., 1921, rev.: E. Romer, Geographical and statistical atlas of Poland. "Geographical Review" Vol. 11, pp. 308-309.

Mościbroda J., Sirko M., 2004, Mapy społeczno-gospodarcze w atlasach Eugeniusza Romera. In: Eugeniusz Romer - geograf i kartograf trzech epok. Materiały sesji naukowej. Warszawa 16 kwietnia 2004 rok. „Studia i Materiały z Historii Kartografii" T. 19, Warszawa, pp. 88-94.

Pawłowski S., 1916, rev.: Romer E., Geograficzno-statystyczny atlas Polski. „Kosmos” R. 41, pp. 205-210; Pawłowski S., 1923/24, rev.: Romer E., Geograficzno-statystyczny atlas Polski. Wyd. drugie. „Polski Przegląd Kartograficzny” T. 1, nr 5, pp. 207-208.

Ratajski L., 1965, Polska kartografia ekonomiczna XX wieku. „Prace Geograficzne” Nr 49, IG PAN, Warszawa.

Romer E., 1917, Polemika. W sprawie naukowych podstaw Atlasu Polski i kompetencji jego oceny (Odpowiedź panu Tadeuszowi Brzeskiemu). „Kwartalnik Historyczny" T. 31, z. 4, pp. 569-586. nal image of the nationality ratios in Upper Silesia and the former Duchy of Cieszyn, and also contained several historical maps on the whole territory of Poland within the partition borders, as well as those established as a result of the war and ratified by the Treaty of Versailles. Although the territorial order established at the time did not even survive a generation, it was of great significance as the starting point for the changes that took place in the Europe in which we live today. It is therefore worth remembering the extent to which thematic cartography was an effective method, even a weapon, in the argument for Polish national interests during the process of convincing the world of the existence of Poland, not only on the map.

Romer Ed., 1980, Historia powstania Geograficzno-statystycznego atlasu Polski Eugeniusza Romera (wspomnienie syna). „Studia i Materiały z Dziejów Nauki Polskiej” Seria C, z. 24, pp. 5-13.

Staszic S., 1807, O statystyce Polski krótki rzut wiadomości, potrzebnych tym, którzy ten kraj chcą oswobodzić, i tym, którzy chcą w nim rządzić. Warszawa.

Sujkowski A., 1917, rev.: Geograficzno-statystyczny atlas Polski. „Muzeum” R. 32, pp. 359-375.

Uhorczak F., 1955, Bibliografia prac prof. E. Romera. „Czasopismo Geograficzne” T. 26, z. 1-2, pp. 6-31.

Wilk W., 1999, Geneza i znaczenie „Geograficzno-statystycznego atlasu Polski”. In: D. Jędrzejczyk, W. Wilk, Eugeniusz Romer jako geograf społeczno-gospodarczy. Warszawa, pp. 115-135.

\section{Cartographic sources}

Romer E., 1916a, Wojenno-polityczna mapa Polski, 1:5,000,000. Lwów.

Romer E., 1916b, Geograficzno-statystyczny atlas Polski, redagowany i opracowany przez Dra Eugeniusza Romera. Nakładem Polskich Spółek Oszczędności i Pożyczek pozostających pod Patronatem Wydziału Krajowego. Warszawa i Kraków.

Romer E., (Ed.), 1921, Polski atlas kongresowy. Atlas des problèmes territoriaux de la Pologne, Nakładem Książnicy Polskiej Towarzystwa Nauczycieli Szkół Wyższych. Z Drukarni Ludowego Spółdzielczego Towarzystwa we Lwowie.

Sotzmann D.F., 1810, Polen nach dem Frieden von Vien 1809 den 14 oct. begränzt. Nürnberg.

Staszic S., 1815, Carta Geologica totius Poloniae, Moldaviae, Transilvaniae et partis Hungariae, et Valachiae. Inventa per Staszic anno 1806. Warszawa. 